\begin{tabular}{l|l|l} 
Jurnal Eksplorasi Akuntansi \\
Vol. 2, No 4, Seri A, November 2020, Hal 3468-3484
\end{tabular} \mid $\begin{aligned} & \text { ISSN : 2656-3649 (Online) } \\
& \text { http://jea.ppj.unp.ac.id/index.php/jea/issue/view/29 }\end{aligned}$

\title{
Analisis Efek Ratcheting Pada Pendapatan Asli Daerah Terhadap Belanja Daerah Di Kabupaten/ Kota Di Provinsi Sumatera Barat, Riau Dan Jambi Tahun 2015-2018
}

\author{
Chaterine Anjeli ${ }^{1}$, Erly Mulyani ${ }^{2}$ \\ ${ }^{1}$ Alumni Jurusan Akuntansi Fakultas Ekonomi Universitas Negeri Padang \\ ${ }^{2}$ Jurusan Akuntansi Fakultas Ekonomi Universitas Negeri Padang \\ *Korespondensi: chaterineanjeli25@gmail.com
}

\begin{abstract}
Abstrak: Mengetahui pengaruh pendapatan asli daerah terhadap belanja daerah serta mengetahui pengaruh efek ratcheting terhadap hubungan antara pendapatan asli daerah dengan belanja daerah Pemerintah kabupaten/kota di Sumatera Barat, Riau dan Jambi merupakan tujuan dari penelitian ini. Populasi dalam penelitian ini adalah kabupaten/kota di Sumatera Barat, Riau dan Jambi yang terdiri dari 19 kabupaten/kota, kabupaten/ kota di Sumatera Barat 12 Kabupaten/ Kota di Riau dan terdiri dari 11 Kabupaten/Kota di Jambi pada tahun 20152018. Metode regresi berganda dengan perangkat lunak spss yang digunakan dalam penelitian ini. Hasil dari penelitian ini adalah, pertama menunjukkan bahwa variabel pendapatan asli daerah berpengaruh positif signifikan terhadap belanja daerah, sedangkan variabel efek ratcheting sebagai moderasi memperlemah terhadap hubungan pendapatan asli daerah terhadap belanja daerah
\end{abstract}

Kata kunci : pendapatan asli daerah, efek ratcheting

How to cite (APA $6^{\text {th }}$ style):

Anjeli, C. \& Mulyani, E. (2019). Analisis Efek Ratcheting Pada Pendapatan Asli Daerah Terhadap Belanja Daerah Di Kabupaten/ Kota Di Provinsi Sumatera Barat, Riau Dan Jambi Tahun 2015-2018. Jurnal Eksplorasi Akuntansi, 2(4), Seri A. 3468-3484.

\section{PENDAHULUAN}

Perkembangan otonomi daerah di negara Indonesia berlaku semenjak ditetapkan UndangUndang No. 32 Tahun 2004 tentang otonomi daerah. Perubahan-perubahan yang sungguh besar di dalam pengelolaan keuangan negara terjadi saat otonomi daerah diterapkan di Indonesia. Proses dalam pengelolaan keuangan daerah ini, daerah mempunyai anggaran. Anggaran daerah tersebut biasanya disebut dengan APBD atau anggaran pendapatan dan belanja daerah.

Anggaran menurut Bastian (2006) adalah satu periode mendatang menginginkan untuk terjadinya suatu paket dari pernyataan estimasi penerimaan dan pengeluaran. Pengukutan kinerja pemerintah daerah di Indonesia salah satunya adalah dengan cara melihat anggaran pemerintah daerah yaitu membandingkan antara realisasi dan anggaran pemerintah daerah tersebut. Sistem anggaran berbasis kinerja pada saat ini sudah diterapkan pada pemerintahan di Indonesia. Sistem 
anggaran berbasis kinerja guna diterapkan agar dapat pemerintah daerah diyakini untuk dapat mengukur kinerja keuangannya yang terpampang didalam APBDnya.

APBD perancangannya dimulai dengan penyusunan RKPD, kemudian melakukan penyusunan RKU. Pihak eksekutif dan pihak legislatif dalam proses perancangan dan penyusunan APBD tersebut akan membentuk suatu pola hubungan yang secara partisipatif dengan tujuan untuk melakukan pembahasan penetapan prioritas dan plafon anggaran sementara yang akan menjadi acuan oleh SKPD dan juga pemerintah daerah. Hal tersebut akan memperlihatkan bahwa kepala daerah dan DPRD akan saling bekerja sama dalam melakukan proses penyusunan APBD yang akan menimbulkan hubungan keagenan, yaitu melakukan kerjasama agar memperoleh APBD yang tepat dengan sasaran.

APBD memiliki beberapa unit yaitu pendapatan daerah, belanja daerah dan pembiayaan daerah ( Peraturan Menteri Dalam Negeri N0. 59 Tahun 2007 ). Pendapatan Asli daerah yang dinyatakan pada UU No 33 Tahun 2004 adalah suatu pendapatan yang langsung diperoleh oleh daerah berdasarkan pada perda yang sudah diatur serta pada praktiknya pendapatan asli daerah juga ditarik sesuai sama peraturan daerah yang berlandasan kepada perundang-undangan. Belanja daerah merupakan suatu pengeluaran yang akan dikeluarkan oleh pemerintah daerah dari rekening kas umum daeah akan dapat mengurangi saldo anggaran pada periode bersangkutan, dan pengeluaran yang dikeluarkan oleh pemerintah daerah tersebut tidak akan bisa didapatkan lagi oleh pemerintah untuk pembayarannya(Peraturan Pemerintah Nomor 71 tahun 2010).

Penentuan besaran alokasi anggaran untuk periode berikutnya, biasanya dapat dilakukan dengan cara melihat kinerja anggaran sebagai basis penilaian prestasi manajemen. Penggunaan anggaran sebagau acuan dalam penentuan anggaran pada periode berikutnya menggambarkan konteks yang menandakan inkrementalisme atas anggaran. Inkrementalisme mempunyai asosiatif negatif, yang bermaksud apabila anggaran periode sebelumnya memuat suatu bias akibat dari perilaku oportunistik penyusun anggaran yang berbentuk penciptaan, yang biasa diberi nama dengan efek ratcheting atau ratchet anggaran.

Halim dan Abdullah (2006) menjelaskan bahwa ratchet akan memperlihakan bahwa akan terjadinya teory agency pada pelaksanaannya, teori agency juga menjelaskan bahwa terjadinya kesepakatan antara dua belah pihak yaitu yang memberi wewenang biasa disebut dengan principal dan pihak yang menerima wewenang disebut dengan agent. Penelitian Abdullah dan Junita (2016) menjelaskan bahwa saat pemerintah daerah menjadikan informasi dari tahun lalu yang bersifat menguntungkan yang akan dijadikan dasar atas penentuan anggaran ditahun berikutnya maka disebut dengan efek ratcheting. Efek ratcheting merupakan bentuk bias perilaku oleh penyusun anggaran dalam proses penentuan atau perencanaan anggaran dan juga merupakan bentuk bias perilaku yang hampir selalu timbul didalam hubungan keagenan selang principal dan agent (Indjejikian \& Nanda, 1999). Efek Ratcheting adalah cara pemerintah daerah dengan mempercantik, merenovasi dan merevisi atas ketercapaian target untuk mendapatkan gambaran pada kinerja dimasa lampau (Nurhayati, 2018).

Hasil penelitian Lim (2011) menunjukkan bahwasa timbulnya permasalahan pada penetapan target anggaran pada pemerintah daerah akan dapat menyebabkan terjadinya budget ratcheting. Penelitian tentang efek ratcheting ini penting untuk dilakukan dalam sector pemerintahan dikarenakan oleh beberapa hal. Pertama, efek ratcheting dapat menunjukkan bias dan perilaku dari penyusun anggaran yang akan bisa menjelaskan faktor penentu dari pertumbuhan anggaran pemerintah, yang mana efek ratcheting dapat terlihat pada saat proses penyusunan anggaran organisasi pemerintah tersebut. Kedua, efek ratcheting menunjukkan bahwa anggaran untuk periode mendatang memuat inkrementaslisme yang tidak seimbang yang 
bertujuan untuk penerapan ABK dalam upaya peningkatan akurasi prosedur perencanaan dan mempererat akuntabilitas kinerja pada siklus penganggaran.

Kasus kenaikan dan perubahan anggaran tersebut terjadi pada Provinsi Sumatera Barat, Riau dan Jambi pada tahun 2018. Kenaikan dan perubahan anggaran tersebut dapat dilihat pada laporan APBD yang dipublikasi oleh www.djpk.kemenkeu.go.id/portal/data/apbd. Laporan yang dipublikasi tersebut memaparkan bahwa anggaran pendapatan pada Provinsi Sumatera Barat mengalami peningkatan sekitar 12\% yang mana pada tahun 2017 sebesar 2 Triliun dan meningkat pada tahun 2018 menjadi 2,3 Triliun. Kenaikan dan perubahan anggaran tersebut dapat juga dilihat pada Provinsi Riau. Provinsi Riau anggaran pendapatan meningkat sekitar 5,7\% yaitu pada tahun 2017 sebesar 3,7 Triilun dan meningkat pada tahun 2018 menjadi 3,9 triliun. Provinsi Jambi juga mengalami peningkatan yaitu meningkat sekitar $6,8 \%$ yaitu pada tahun 2017 sebesar 1,3 Triliun dan meningkat pada tahun 2018 menjadi 1,4 Triliun.

Belanja daerah pada tahun 2018 meningkat sebesar 6, 27\% sebesar yaitu pada tahun 2017 sebesar 6,2 Triliun meningkat menjadi 6,6 Triluin di Provinsi Sumatera Barat. Pada provinsi Jambi mengalami peningkatan sebesar 3,8\% pada tahun 2018 yaitu pada tahun 2017 4,3 dan meningkat menjadi 4,5 pada tahun 2018. Maka dari itu, belanja daerah yang mengalami peningkatan ini dapat disimpulkan bahwa belanja daerah mengalami varian negatif. Keadaan ini menandakan bahwasanya capaian realisasi membutuhkan peningkatan dari pelaksanaan dan perencanaan anggaran yang telah direncanakan. Maka dari itu, berdasarkan kasus dari perubahan dan peningkatan tersebut kita perlu melihat apakah terjadi efek ratcheting pada pendapatan asli daerah terhadap belanja daerah.

Penelitian Andrean \& Sari (2020) dalam hasilnya penelitiannya menemukan bahwa terjadinya budget ratcheting dalam memengaruhi hubungan antara pendapatan asli daerah dengan belanja daerah. Penelitian ini melanjutkan penelitian yang dilaksanakan oleh Andrean \& Sari dengan memperluas atau menambah cakupan atas sampel dari penelitiannya. Maka penelitian ini akan melihat pengaruh pendapatan asli daerah dengan belanja daerah dan melihat apakah terjadi budget ratcheting dalam memengaruhi hubungan antara pendapatan asli daerah dengan belanja daerah pada Provinsi Sumatera Barat, Riau, dan Jambi.

\section{REVIU LITERATUR DAN HIPOTESIS \\ Teori Keagenan}

Suatu fenomena biasanya sering ditemukan dalam suatu organisasi baik pada sektor privat maupun sektor publik merupakan penjelasan dari teori keagenan. Hubungan keagenan merupakan suatu komitmen diantara pihak principal dan agent, dimana pihak principal akan memperkejakan pihak agent untuk megasihkan sebuah jasa dan selanjutnya mengamanatkan wewenang pengambil keputusan tersebut (Jensen dan Mackling, 1976).

Teori keagenan dalam penelitian ini memiliki hubungan, yaitu hubungan antara masyarakat yang mewakili DPRD (principal) dan pemerintah daerah (agen) (Ardiansyah et al, 2014). DPRD (principal) mengevaluasi kinerja penyelenggaraan pemerintahan daerah (eksekutif) yang mengutamakan kebijakan yang dicapai oleh pemerintah atau mengutamakan kepentingan rakyat.

\section{Belanja Daerah}

BD adalah seluruh kewajiban daerah khusus yang bertindak sebagai upaya untuk mengurangi kekayaan bersih dalam periode tahun anggaran atau tahun buku yang berkaitan, yang diatur dengan undang-undang nomor. 33 Tahun 2004. Belanja daerah adalah penggunaan sumber daya 
untuk menyelenggarakan kegiatan pemerintahan untuk dijadikan kewenangan suatu kabupaten atau daerah / kota yang mencakup urusan wajib dan pilihan.

\section{Anggaran Pendapatan dan Belanja Daerah}

Anggaran Pendapatan dan Belanja Daerah sesuai Permendagri Nomor 21 Tahun 2011 merupakan agenda atau rencana keuangan tahunan pemerintah daerah yang akan ditinjau dan disetujui oleh pemerintah daerah dan DPRD, serta akan dilakukan penyesuaian sesuai dengan peraturan daerah.

Anggaran pendapatan dan belanja daerah merupakan alat kebijakan utama bagi pemerintah daerah. Anggaran daerah juga digunakan sebagai bahan dalam menentukan besaran pendapatan dan pembiayaan. Anggaran daerah akan dapat membantu dalam membuat keputusan dan desain dalam pembangunan, serta mengesahkan pengeluaran di masa depan.

\section{Anggaran}

Anggaran diartikan sebagai paket pernyataan perkiraan penerimaan dalam penerimaan ataupun pengeluaran yang diharapkan terjadi pada periode berikutnya (Bastian, 2006). Anggaran menurut GASB (Governmental Accounting Standards Boards) adalah rencana proses keuangan yang diperkirakan dari estimasi dan merupakan sumber pendapatan bagi penyandang dana untuk pembiayaan dalam suatu periode tertentu.

Anggaran berfungsi sebagai alat perencanaan, alat pengendalian, alat kebijakan, alat politik, alat koordinasi dan komunikasi, alat penilaian kinerja dan alat motivasi. Jenis-jenis anggaran menurut (Bastian, 2006) adalah Line Item Budgeting, Incremental Budgeting, Planning Programming Budgeting System, Zero Based Budgeting, Perfomance Budgeting, Medium Term Budgeting Framework.

\section{Pendapatan asli daerah}

Pendapatan asli daerah adalah pendapatan yang diperoleh pada pungutan atas peraturan daerah masing-masing yang mana dilandasi dengan perundangan-undangan yang dinyatakan dalam Undang-Undang No. 33 tahun 2004. PAD juga dapat dikatakan seluruh penerimaan daerah yang bersumber dari sumber ekonomi asli dari daerah tersebut. Pendapatan asli daerah diakui saat adanya pemerintah daerah menerima pajak yang mana diantaranya yaitu pajak property, pajak pendapatan dan pajak penjualan, denda dan lisensi, transfer dari antar pemerintah dan pendapatan lain-lain.

Pemerintah daerah mempunyai potensi yang mana akan menjadi sumber pendapatan daerah itu sendiri, dan dasar dari penguatan tersebut yaitu dari peraturan perundang-undangan yang berlaku. Peraturan daerah yang sudah diterbitkan diharapkan agar dapat terjadinya peningkatan kemampuan daerah dalam pembiayaan pembangunan daerah dan juga pelayanan publik atas landasan kebutuhan dan dapatnya mengurangkan ketergantungan pemerintah daerah terhadap pemerintah pusat.

\section{Efek Ratcheting}

Ratcheting adalah suatu bentuk asimetri informasi, yaitu adanya ketidakstabilan informasi diantara principal dan agent (Leone \& Rock,2002) dan Fisher, et al (2002) menemukan bahwasanya ratcheting ini bersifat simetris didalam perilaku. Aranda, Arellano dan Davila (2010) menjelaskan tujuan Ratcheting adalah untuk meminimalisir ketidakseimbangan anggaran dan berdampak pada biaya yang dikeluarkan dalam penganggaran partisipatif. 
Efek Ratchet adalah suatu bentuk bias dari perilaku penyusun anggaran dalam proses penentuan atau perencanaan anggaran. Efek Ratchet adalah suatu bentuk bias perilaku yang mana hampir selalu muncul dalam hubungan keagenan antara principal dan agen (Indjejikian \& Nanda, 1999). Efek ratchet muncul ketika perancang anggaran menetapkan tujuan anggaran berdasarkan pencapaian kinerja anggaran periode sebelumnya sebagai akibat dari masalah insentif dinamis dalam konteks hubungan keagenan.

Dampak ratchet terhadap anggaran ditunjukkan dalam bentuk perilaku eksekutif oportunistik dengan mengubah atau merilis pencapaian anggaran tahun berjalan sebelum atau menjelang akhir periode anggaran. Efek ratchet dalam penelitian ini yang mana pengukuran variabelnya menggunakan model Aranda et, al (2010).

\section{Hubungan antara Pendapatan Asli Daerah dengan Belanja Daerah}

Penganggaran pendapatan asli daerah merupakan suatu tahapan dalam penentuan target pendapatan yang mana biasanya dilaksanakan dengan menimang-nimang peraturan terkait dengan objek pendapatan yang khas seperti (Undang-Undang, Peraturan Pemerintah, Peraturan Daerah.

Penelitian terdahulu yang meneliti tentang hubungan antara pendapatan asli daerah terhadap belanja daerah yaitu Abdullah dan Junita (2016), Rahmawati (2015), dan Sari,dkk (2019) menyimpulkan kalau pendapatan asli daerah berpengaruh signifikan terhadap belanja daerah. Penelitian tersebut dapat disimpulkan bahwa melalui pendapatan asli daerah yang tinggi, maka dapat disimpulkan bahwa pemerintah dapat menurunkan ketergantungannya terhadap pemerintah daerah. Penelitian itu juga dapat disimpulkan bahwasanya pemerintah daerah yang mempunyai pendapatan asli daerah yang relatif tinggi maka dari itu pengeluaran yang digunakan untuk alokasi belanja daerahnya juga akan semakin besar. Dana yang diterima lewat pendapatan asli daerah apabila besar maka juga akan semakin besar juga dana yang akan dan harus dialokasikan pada belanja daerah.

H1: Pendapatan asli daerah berpengaruh positif signifikan terhadap belanja daerah

\section{Hubungan antara Efek Ratcheting terhadap Hubungan Pendapatan Asli Daerah dengan Belanja Daerah}

Pengaruh kenaikan anggaran akan terwujud dalam bentuk perilaku eksekutif oportunistik dengan mengubah pencapaian anggaran tahun berjalan pada akhir periode. Ekonomi politik di pemerintah daerah menghubungkan birokrat dan ini dapat dilihat melalui upaya memaksimalkan anggaran ini, dan pemerintah daerah biasanya mendapatkan keuntungan dari kekuatan monopoli yang mereka nikmati (Lee \& Plummer, 2007).

Penelitian yang dilakukan oleh Abdullah dan Junita (2016) mengatakan dalam penelitiannya bahwa hubungan dari budget ratcheting memoderasi hubungan pendapatan sendiri dengan belanja daerah. Penelitian yang dilakukan sari, dkk (2019) hasil analisisnya adalah budget ratcheting memperkuat hubungan antara pendapatan asli daerah dengan belanja daerah. Hasil dari penelitian tersebut mendukung bahwa dalam anggaran terdapat terjadinya masalah keagenan pada penganggaran daerah, dimana akan terlihat pada saat pengusul anggaran dan yang menyetujui untuk usulan anggaran itu mempunyai kepentingan pribadi yang kemudian akan diakomodir di dalam anggaran atau moral hazard.

H2: efek ratcheting berpengaruh positif signifikan terhadap hubungan antara pendapatan asli daerah dengan belanja daerah. 
Kerangka Konseptual

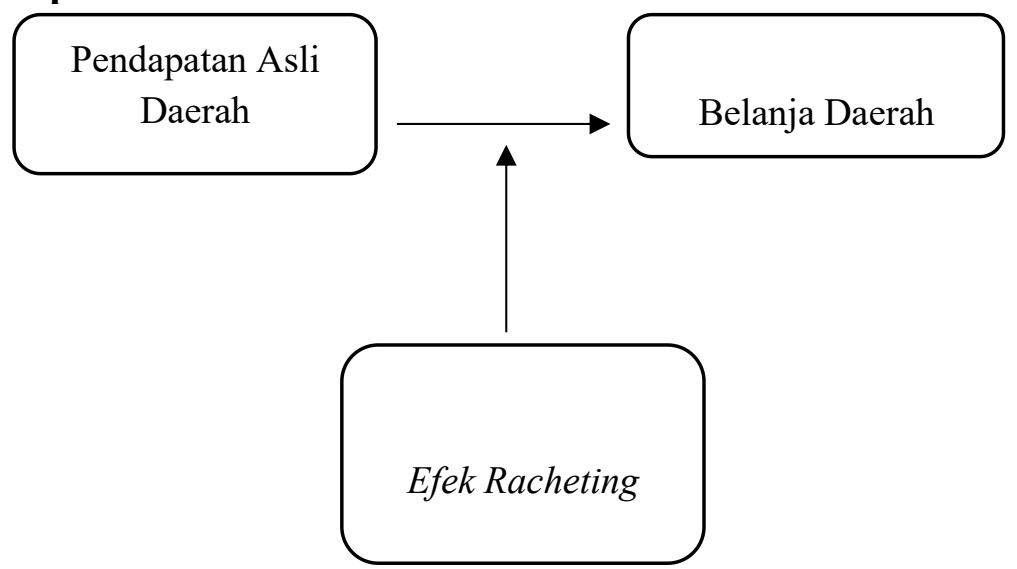

\section{Gambar 1. Kerangka Konseptual}

\section{METODE PENELITIAN}

\section{Jenis dan Objek Penelitian}

Kuantitatif deskriptif merupakan jenis dari penelitian ini. Objek yang akan diteliti adalah anggaran dari Pendapatan Asli Daerah dan Belanja Daerah pada laporan realisasi anggaran Kabupaten/Kota di Sumatera Barat, Riau dan Jambi dari tahun 2015 - 2018.

\section{Populasi dan Sampel}

Seluruh Kabupaten/ Kota di Provinsi Sumbar, Riau dan Jambi dari tahun 2015-2018, total populasi sejumlah 168, dimana merupakan populasi dari penelitian ini. Sampel penelitian adalah total populasi yang biasa disebut sampel jenuh dengan metode sensus.

\section{Jenis data dan Sumber Data}

Jenis Data

Data skripsi ini berjenis data dokumentasi. Data dokumentasi bertujuan untuk mengumpulkan data dari berbagai sumber baik pada level personal maupun korporat, data berupa laporan keuangan, ringkasan karyawan, struktur organisasi, regulasi, data produksi, wasiat, resume, dan history perusahaan yang biasanya terdapat di situs penelitian (Sanusi, 2011) .

\section{Sumber Data}

Data sekunder merupakan sumber data dari penelitian ini. Data yang digunakan adalah APBD dipublikasi oleh djpk.kemenkeu.go.id

\section{Variabel Penelitian}

Variabel Moderasi

Efek ratcheting merupakan variabel moderasi dalam penelitian ini.

\section{Variabel Independen}

Pendapatan Asli Daerah merupakan variabel independent dalam penelitian ini

\section{Variabel dependen}

Belanja daerah merupakan variabel dependen dalam penelitian ini. 


\section{Pengukuran Variabel}

1. Belanja Daerah

$$
\begin{gathered}
\text { Belanja Daerah = Belanja Operasi + Belanja Modal + Belanja Tak } \\
\text { Terduga }
\end{gathered}
$$

Sumber : Peraturan Pemerintah No. 71 tahun 2010

\section{Pendapatan Asli Daerah}

\begin{aligned} & PAD $=$ Total Pajak Daerah + Total Retribusi Daerah + Hasil \\ & Pengelolaan Kekayaan Daerah yang Dipisahkan + Lain- \\ & Lain Pendapatan Asli Daerah yang Sah \\ & \hline\end{aligned}

Sumber : Peraturan Pemerintah No. 71 tahun 2010

\section{Budget Ratcheting}

Pengukuran tentang efek ratcheting dilakukan dengan menggunakan model dari Aranda, et al. (2010), yang mana rumusnya sebagai berikut:

$$
\mathrm{PAD}_{\mathrm{t}}-\mathrm{PAD}_{\mathrm{t}-1}=\delta+\gamma\left(\mathrm{PADR}_{\mathrm{t}-1}-\mathrm{PAD}_{\mathrm{t}-1}\right)+\varepsilon,
$$

\section{Teknik Analisis Data}

\section{Analisis Deskriptif}

Memberikan penjelasan tentang gambaran umum demografi dan gambaran variabel penelitian yang bertujuan untuk menentukan distribusi frekuensi absolut adalah tujuan dari analisis deskriptif ini.

\section{Uji Asumsi Klasik}

Uji asumsi klasik yang terdiri dari uji normalitas, uji multikolinieritas, uji heterokedastisitas dan uji autokorelasi.
a. Uji Normalitas
Untuk menguji dari suatu data, sudahkah data distribusi dari sebuah data tersebut berdistribusi normal merupakan tujuan dari melakukan uji normalitas.
b. Uji Multikolinieritas
Tujuan uji multikolinieritas dilakukan adalan mendeteksi gejala korelasi antara variabel independent.
c. Uji Heterokedastisitas
Tujuan dilakukan uji heterokedastisitas adalah untuk menguji apakah dalam sebuah model regresi terjadi perbedaan atas suatu pengamatan ke pengamatan yang lain.
d. Uji Autokorelasi
Tujuan dari uji korelasi otomatis adalah untuk menguji apakah terdapat korelasi dalam model regresi linier antara kesalahan perancu pada periode $t$ dengan kesalahan perancu pada periode $\mathrm{t}-1$ atau sebelumnya.

\section{Uji Hipotesis}

\section{a. Uji Regresi Linear Berganda}

Model regresi linear berganda dalam penelitian ini digunakan untuk menguji semua hipotesis. Tujuan dari regresi berganda ini adalah melihat besar dari pengaruh suatu variabel independent terhadap variabel dependen. 
Persamaan regresi pada penelitian ini :

$$
\begin{gathered}
\mathrm{Y}=\mathrm{a}+\beta 1 \mathrm{X} 1+\mathrm{e} \text { persamaan }(1) \\
\mathrm{Y}=\mathrm{a}+\beta 1 \mathrm{X} 1+\beta 2 \mathrm{X} 2+\beta 3 \mathrm{X} 1 * \mathrm{X} 2+\mathrm{e} \text { persamaan }(2)
\end{gathered}
$$

b. Uji Koefisien Determinasi

Tujuan dari uji ini untuk melihat dari kepantasan penelitian yang peneliti lakukan ini, dimana melihat kepantasan tersebut dengan cara melihat pengaruh antara variabel bebas terhadap variabel terikat.

c. Uji t

Rumus uji ini adalah:

$$
\text { Adjusted } R^{2}=1-\left(1-R^{2}\right)
$$

Uji ini dilakuakan dengan tujuan agar dapat mengetahu adakah kontras mean yang signifikan pada suatu variabel terikat antara dua kelompok.

d. Uji F

Melakukan uji ini agar dapat mengetahui pengaruh semua variabel bebas sevara bersama-sama terhadap variabel terikat atau untuk menguji sudahkah model regresi yang digunakan signifikan atau tidak.

\section{HASIL DAN PEMBAHASAN}

Analisis Deskriptif

Variabel Belanja Daerah yang sudah dihitung dengan beberapa penjumlahan atas pos-pos pendapatan yang telah disajikan pada Laporan Realisasi Anggaran memiliki rentang nilai dari 11,68 sampai dengan 12,66. Belanja daerah mempunyai nilai rata-rata (mean) sebesar 12,0636 dan juga memiliki nilai standar deviasi sebesar 0,17759 .

\section{Tabel 1}

Hasil statistik deskriptif

\begin{tabular}{lrrrrr}
\hline \multicolumn{7}{c}{ Descriptive Statistics } \\
\hline & N & Minimum & Maximum & Mean & \multicolumn{1}{c}{ Std. Deviation } \\
\hline Belanja Daerah & 168 & 11,68 & 12,66 & 12,0636 &, 17759 \\
\hline Pendapatan Asli Daerah & 168 & 10,47 & 11,84 & 11,0025 &, 28588 \\
\hline Budget Racheting & 168 &, 00 & 2,72 & 2,6654 &, 20705 \\
\hline Valid N (listwise) & 168 & & & & \\
\hline
\end{tabular}

Sumber: Data diolah peneliti menggunakan spss

Pendapatan Asli Daerah yang telah dihitung dengan penjumlahan atas pos-pos pendapatan yang ada pada laporan realisasi anggaran memiliki rentang nilai mulai dari 10,47 sampai dengan 11,84. PAD mempunyai nilai rata-rata 11,0025 dan nilai standar deviasi sebesar 0,28588. Variabel Budget Ratcheting yang dihitung menggunakan model Aranda (2010) mempunyai bentang nilai mulai dari 0,00 sampai dengan 2,72 dan memiliki nilai mean sebesar 2,6654 dan juga mempunyai nilai standar deviasi sebesar 0,20705. 


\section{Uji Normalias}

Tabel 2

Hasil Uji Normalitas

\begin{tabular}{llr}
\hline \multicolumn{3}{c}{ One-Sample Kolmogorov-Smirnov Test } \\
\hline $\mathrm{N}$ & \multicolumn{1}{c}{$\begin{array}{c}\text { Unstandardized } \\
\text { Residual }\end{array}$} \\
\hline \multirow{2}{*}{ Normal Parameters ${ }^{\mathrm{a}, \mathrm{b}}$} & Mean & 168 \\
\cline { 2 - 3 } & Std. Deviation & $0 \mathrm{E}-7$ \\
\hline \multirow{2}{*}{ Most Extreme Differences } & Absolute &, 060 \\
\cline { 2 - 3 } & Positive &, 038 \\
\cline { 2 - 3 } & Negative &,- 060 \\
\hline Kolmogorov-Smirnov Z & &, 776 \\
\hline Asymp. Sig. (2-tailed) & &, 584 \\
\hline a. Test distribution is Normal. \\
\hline \multicolumn{2}{l}{ b. Calculated from data. } \\
\hline
\end{tabular}

Data diatas dapat disimpulkan tingkat signifikansi pada variabel ini berdistribusi secara normal karena $0,584>0,05$.

\section{Uji Asumsi Klasik}

\section{a. Uji Multikoliniearitas}

Data diatas menyimpulkan tidak terjadinya multikolinieritas karena sudah memenuhi syarat bebas dari multikolonieritas, dimana pada pendapatan asli daerah dan budget ratcheting memiliki tolerance $>0,1$ dan $\mathrm{VIF}<10$

Tabel 3

Hasil Uji Multikolinieritas

\begin{tabular}{|c|c|c|c|}
\hline \multicolumn{4}{|c|}{ Coefficients $^{\mathbf{a}}$} \\
\hline \multirow[t]{2}{*}{ Model } & & \multicolumn{2}{|c|}{ Collinearity Statistics } \\
\hline & & Tolerance & VIF \\
\hline \multirow{3}{*}{1} & (Constant) & & \\
\hline & Pendapatan Asli Daerah & ,976 & 1,025 \\
\hline & Budget Racheting & ,976 & 1,025 \\
\hline
\end{tabular}

Data diatas menyimpulkan tidak terjadinya multikolinieritas karena sudah memenuhi syarat bebas dari multikolonieritas, dimana pada pendapatan asli daerah dan budget ratcheting memiliki tolerance $>0,1$ dan $\mathrm{VIF}<10$ 


\section{b. Uji Heterokedastisitas}

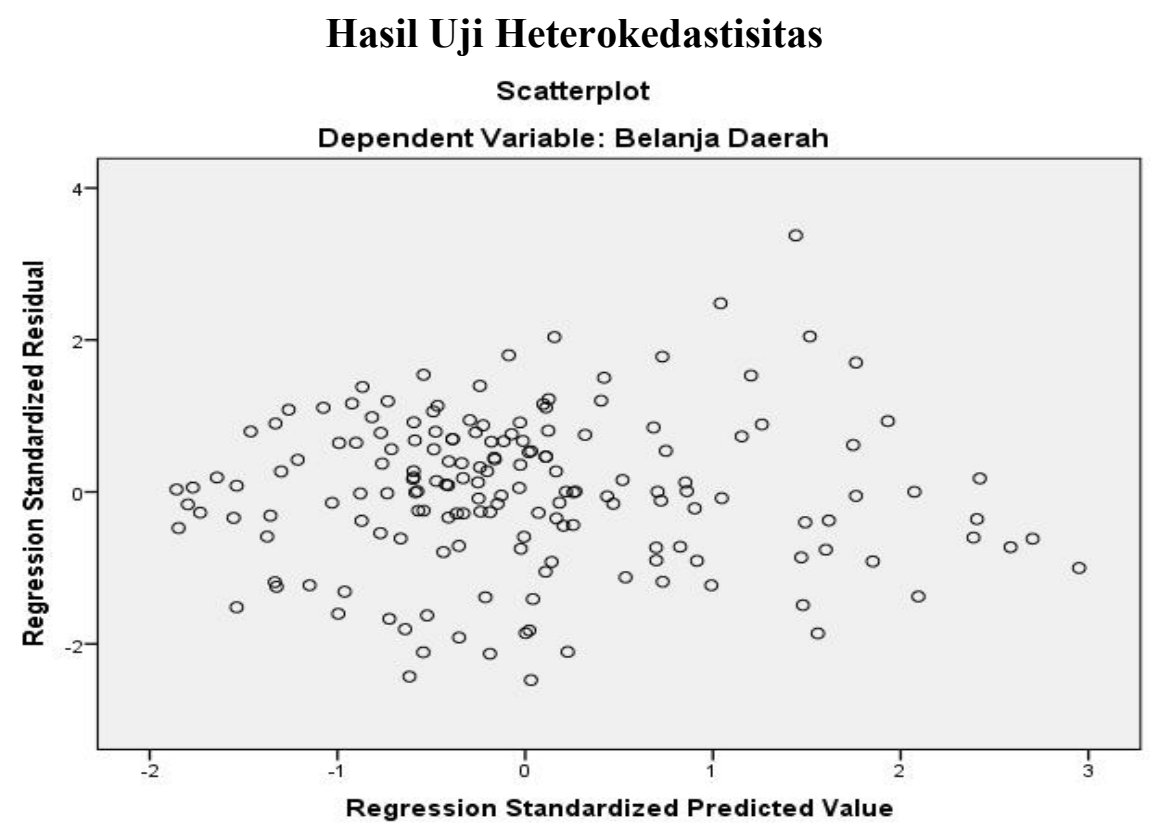

Gambar 2. Uji Heterokedastisitas (Sumber: data sekunder diolah melalui SPSS)

Disimpulkan dari gambar diatas bahwa variabel dalam penelitian ini tidak terjadinya heterokedastisitas, karena pola titiknya menyebar luas beracakan.

\section{c. Uji Autokorelasi}

Tabel di bawah menyimpulkan bahwa tidak terjadinya autokorelasi atau penelitian secara model regresi ini dapat diterima. Tidak adanya korelasi terbukti pada tabel diatas memperoleh nilai Durbin-Watson atau DW sebesar 0,513 , artinya DW berada pada rentang -2 sampai +2

\section{Tabel 4}

Hasil Uji Autokorelasi Model Summary ${ }^{\text {b }}$

\begin{tabular}{ll}
\multicolumn{2}{c}{ Model Summary $^{\mathbf{b}}$} \\
\hline Model & Durbin-Watson \\
\hline 1 &, 513 \\
\hline a. Predictors: (Constant), Budget Racheting, Pendapatan Asli Daerah \\
\hline b. Dependent Variable: Belanja Daerah \\
\hline Sumber: Data Sekunder diolah melalui SPSS
\end{tabular}




\section{Analisis Regresi Sederhana}

\section{Tabel 5}

Hasil Estimasi Analisis Regresi Sederhana

\begin{tabular}{|ll|r|r|r|}
\hline \multirow{2}{*}{ Model } & \multicolumn{2}{|c|}{ Unstandardized Coefficients $^{\text {Unts }}$} & $\begin{array}{c}\text { Standardized } \\
\text { Coefficients }\end{array}$ \\
\cline { 3 - 5 } & & B & Std. Error & \multicolumn{1}{c|}{ Beta } \\
\hline \multirow{2}{*}{1} & (Constant) & 6,989 &, 355 &, 742 \\
\hline
\end{tabular}

a. Dependent Variable: Belanja Daerah

Sumber: Data Sekunder diolah melalui SPSS

Tabel diatas jika dirumuskan berbentuk persamaan regresi sederhana, maka persamaan tersebut sebagai berikut:

$$
\begin{aligned}
& B D=\alpha+b_{1} P A D+e \\
B D= & 6,989+0,461 P A D
\end{aligned}
$$

Hasil persamaan regresi diatas memperlihatkan perolehan nilai koefisien konstanta yaitu sebesar 6,989, yang artinya apabila nilai dari pendapatan asli daerah konstan, dan maka dari itu nilai variabel dependen (Belanja Daerah) besar nilai nya menjadi 6,989. Dapat dilihat juga bahwa nilai dari koefisien regresi Pendapatan Asli Daerah diperoleh sebesar 0,461yang mempunyai arti bahwa jika pendapatan asli daerah mengalami peningkatan satu satuan maka dari itu belanja daerah akan mengalami peningkatan sebesar 0,461 satuan. Kesimpulannya, hasil pnilai koefisien regresi tersebut memperoleh pendapatan asli daerah mempunyai pengaruh positif senilai 0,461 terhadap belanja daerah. Berarti, semakin mengalami peningkatan pada pendapatan asli daerah akan terjadi juga peningkatan pada belanja daerah.

\section{Moderating Regression Analysis}

Persamaan regresi pada tabel memperlihatkan nilai konstanta sebesar 6,984, maka dari itu dapat diartikan apabila ketika nilai variabel independen konstan, mka dari itu besar nilai variabel dependen (Belanja Derah) sebesar 6,976. Sedangkan nilai koefisien regresi Pendapatan Asli Daerah Sumbar mempunyai pengaruh positif senilai 0,460 terhadap Belanja Daerah, artinya semakin meningkat Pendapatan Asli Daerah maka akan terjadi peningkatan pada Belanja Daerah. Sedangkan apabila terjadi penambahan variabel pada variabel moderasi Budget Ratcheting menghasilkan pengaruh negatif terhadap Belanja Daerah sebesar 3,3673. Artinya semakin tinggi Budget Ratcheting maka akan menurunkan Belanja Daerah sebesar 3,3673. 
Hasil dari uji diatas menjelaskan hasil dari perhitungan yang menggunakan SPSS dapat diketahui bahwa Adjusted R Square 0,548 atau 54,8\%. Perihal ini menjelaskan bahwa kesanggupan dari variabel independent dalam menerangkan varians dari variabel dependennya yaitu sebesar $0,548 / 54,8 \%$ berpengaruh terhadap pendapatan asli daerah dan sedangkan yang sisanya sebesar $45,2 \%$ diterangkan oleh variabel lain yang tidak disajikan pada penelitian ini. Tabel Adjusted R Square mengalami penurunan menjadi 0,546 atau 54,6\%. Hasil tersebut menjelaskan bahwa 54,6\% belanja daerah dapat diterangka pendapatan asli daerah dan Budget Ratcheting sebagai variabel moderasi memperlemah dalam memoderasi pendapatan asli daerah terhadap belanja daerah. Sedangkan sisanya, yaitu sebesar $45,4 \%$ belanja daerah diterangkan pada variabel lainnya.

\section{b.Uji F}

Dari perhitungan dan output diatas dapat dilihat bahwa diperoleh nilai Fhitung 101,385 dengan tingkat signifikansi sebesar $0,000<0,005$ dan nilai Fhitung 101,385 $>$ Ftabel 3,05. Maka dari itu dapat ditarik kesimpulan bahwa model yang digunakan untuk penelitian ini dalam menguji pendapatan asli daerah adalah model yang fit. Persamaan regresi ini dapat dikatakan signifikan yang artinya terdapat pengaruh signifikan pendapatan asli daerah dan budget ratcheting terhadap belanja daerah.

\section{Tabel 9}

Hasil Uji F

\begin{tabular}{ccccccc}
\hline \multicolumn{7}{c}{ ANOVA $^{\mathbf{a}}$} \\
\hline \multirow{3}{*}{1} & Model & Sum of Squares & df & Mean Square & F & Sig. \\
\cline { 2 - 7 } & Regression & 2,904 & 2 & 1,452 & 101,385 &, $000^{\mathrm{b}}$ \\
\cline { 2 - 7 } & Residual & 2,363 & 165 &, 014 & & \\
\cline { 2 - 7 } & Total & 5,267 & 167 & & & \\
\hline
\end{tabular}

a. Dependent Variable: Belanja Daerah

b. Predictors: (Constant), PADXBR, Pendapatan Asli Daerah

Sumber: Data Sekunder diolah melalui SPSS

\section{Uji t}

Tabel 10

Hasil Uji Statistik t

\begin{tabular}{|c|c|c|c|c|c|c|}
\hline \multicolumn{7}{|c|}{ Coefficients $^{\mathrm{a}}$} \\
\hline \multirow{2}{*}{\multicolumn{2}{|c|}{ Model }} & \multicolumn{2}{|c|}{ Unstandardized Coefficients } & \multirow{2}{*}{$\begin{array}{c}\text { Standardized } \\
\text { Coefficients } \\
\text { Beta } \\
\end{array}$} & \multirow[t]{2}{*}{$\mathrm{T}$} & \multirow[t]{2}{*}{ Sig. } \\
\hline & & $\mathrm{B}$ & Std. Error & & & \\
\hline \multirow{3}{*}{1} & (Constant) & 6,976 & ,361 & & 19,337 & ,000 \\
\hline & Pendapatan Asli Daerah &, 460 &, 033 & ,740 & 14,002 &, 000 \\
\hline & PADXBR &, 001 &, 004 &, 013 &, 247 &, 805 \\
\hline
\end{tabular}

a. Dependent Variable: Belanja Daerah

Sumber: Data Sekunder diolah melalui SPSS 


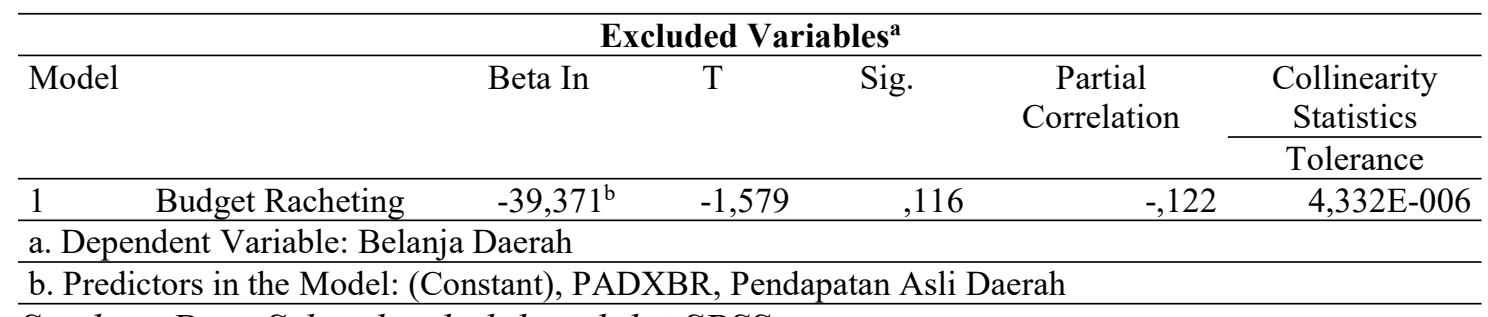

Sumber: Data Sekunder diolah melalui SPSS

Berdasarkan analisis regresi untuk profitabilitas, pendapatan asli daerah memperoleh nilai t hitung $>\mathrm{t}$ tabel yaitu 14,002 $>1,654$. Berdasarkan tabel di atas untuk variabel Pendapatan Asli Daerah diperoleh nilai Sig. sebesar 0,000. Hal ini dapat diartikan bahwa Pendapatan Asli Daerah memberikan pengaruh yang signifikan terhadap Belanja Daerah secara signifikan, dikarenakan nilai 0,000 lebih kecil dari 0,05 (alfa). Sedangkan pada variabel Budget Ratcheting dan Pendapatan Asli Daerah X Budget Ratcheting diperoleh nilai Sig. senilai 0,805 dan 0,116. Hal ini menunjukkan bahwa variabel Budget Ratcheting dan Pendapatan Asli Daerah x Budget Ratcheting tidak memberikan pengaruh yang signifikan terhadap Belanja Daerah, ini dikarenakan 0,805 dan 0,116 lebih besar dari 0,05 (alfa).

\section{PEMBAHASAN}

\section{Pengaruh Pendapatan Asli Daerah terhadap Belanja Daerah}

Pendapatan asli daerah berpengaruh terhadap belanja daerah merupakan pernyataan dari hipotesis pertama. Berdasarkan pengujian data yang dilakukan, diperoleh hasil bahwa pendapatan asli daerah berpengaruh positif dan signifikan terhadap belanja daerah pada Pemerintah Kabupaten / Kota di Provinsi Sumatera Barat, Riau dan Jambi. Hasil uji regresi secara menunjukkan hasil yang signifikan antara variabel pendapatan asli daerah terhadap belanja daerah, dimana signya 0,000 , dan signifikansi yang diperoleh lebih kecil dari nilai toleransi kesalahan $\mathrm{a}=0,05$. Hasil uji $\mathrm{t}$ juga menunjukkan nilai $\mathrm{t}$ hitung $>\mathrm{t}$ tabel, dimana 14.002> 1.654. Nilai koefisien regresi sebesar 0,460 yang mempunyai trend positif, hal ini menunjukkan bahwa semakin banyak pendapatan daerah yang dihasilkan oleh daera makan maka akan semakin banyak pula belanja daerah

Hasil penelitian ini sejalan dengan penelitian yang sudah dilakukan oleh Andrean (2019) diperoleh hasil pendapatan asli daerah berpengaruh signifikan terhadap belanja daerah pada Pemerintah Kota Sumatera Barat. Uji statistic nya memperoleh hasil pengaruh sebesar 0,532 yang memiliki arah positif terhadap belanja daerah, mempunyai arti apabila PAD terjadinya peningkatan dan belanja daerah akan mengalami peningkatan juga. penelitian sebelumnya adapun yang sejalan dengan penelitian ini yaitu penelitian Wati (2017) memberikan hasil bahwa pendapatan asli daerah berpengaruh signifikan terhadap belanja daerah pada Pemerintah Kota Bandung.

\section{Pengaruh Budget Ratcheting terhadap Hubungan antara Pendapatan Asli Daerah dengan Belanja Daerah}

Adanya pengaruh Budget Ratcheting sebagai moderasi dalam hubungan antara Pendapatan Asli Daerah dengan Belanja Daerah merupakan pernyataan dari hipotesis kedua. Hasil uji dapat dilihat pada tabel nilai Adjusted $R$ Square pada regresi pertama di tabel 4.11 sebesar 0,548\% atau $54,8 \%$, setelah adanya persamaan regresi kedua (MRA) pada tabel 4.12 nilai Adjusted $R$ Square 
turun menjadi 0,546 atau 54,6\%. Maka dari itu dapat disimpulkan bahwa pada Kabupaten/ Kota di Provinsi Sumatera Barat, Riau dan Jambi dapat diketahui bahwa hubungan pendapatan asli daerah dengan belanja daerah diperlemah oleh Budget Ratcheting sebagai variabel moderasi.

Hasil pada uji t dapat dilihat pada tabel 4. 14 nilai sig untuk Budget Ratcheting diperoleh 0,116 dan pendapatan asli daerah $\mathrm{x}$ Budget Ratcheting sebesar 0,805. Maka dari itu dapat disimpulkan hasil uji t pada Kabupaten/ Kota di Provinsi Sumatera Barat, Riau dan Jambi memperlihatkan tidak ada nya pengaruh budget ratcheting dan pendapatan asli daerah $\mathrm{x}$ budget ratcheting karena nilai Sig lebih besar dari nilai alfa $(0,05)$. Penelitian ini memberikan hasil yang sama dengan penelitian yang dilakukan oleh Adrean (2019) yaitu memberikan hasil regresi pertama sebesar 0,374 atau 37,4\% dan angka R Square mengalami penurunan menjadi 0,361 atau $36,1 \%$. Maka hasil tersebut juga memberikan kesimpulan bahwa hubungan pendapatan asli daerah dengan belanja daerah diperlemah oleh budget ratcheting. Tetapi, penelitian ini berbeda dengan hasil penelitian yang dilakukan oleh Nurhayati (2018) yaitu memberikan hasil pada regresi pertama $R$ Square sebesar 0,341 atau $34,1 \%$ dan pada persamaan regresi kedua diperoleh peningkatan pada $R$ Square nya yaitu sebesar 0,358 atau 35,8\%. Maka dapat disimpulkan dari hasil penelitian Nurhayati (2018) menyatakan Budget Ratcheting memperkuat antara hubungan pendapatan asli daerah dengan belanja daerah.

Penelitian yang dilakukan oleh Abdullah dan Junita (2016) juga memberikan hasil yang berbeda dengan penelitian ini yaitu hasil penelitiannya pada koefisien regresi pada variabel moderasi yaitu sebesar 0,0000002491 dengan signifikan level $\mathrm{a}=5 \%$, yang memberikan bukti bahwa Budget Ratcheting memiliki efek moderasi dan adanya terjadi hubungan antara pendapatan asli daerah dan belanja daerah. Dan dari uji regresi yang dilakukan juga mendapatkan hasil $R$ Square 0,847 atau $84,7 \%$, pada uji regresi kedua terjadi peningkatan menjadi 0,939 atau 93,9\%. Maka dapat disimpulkan dari hasil penelitian Abdullah dan Junita (2016) yaitu menunjukkan bahwa budget ratcheting dapat memoderasi hubungan antara pendapatan dan belanja daerah.

Penelitian ini juga berbeda dengan hasil penelitian yang dilakukan oleh Smith dan Bertozzi (1998) hasil penelitiannya juga menjelaskan bahwa aktor agency akan terus menerus melakukan pemaksimalan anggaran, tujuannya agar berpengaruh terhadap besaran varian atau selisih anggaran dengan reaslisasinya. Hasil penelitiannya juga memberikan pemikiran yang sejalan yaitu penelitian Isaken (2002) dan Abdullah (2012) memberikan pemikiran bahwa aka nada selalu ruang untuk dapat terjadinya praktik korupsi dalam tahapan penyusunan anggaran. Penelitian yang dilakukan oleh Lee dan Plummer (2007) juga memberikan hasil penelitian bahwa hubungan antara varian anggaran belanja yang tampak overspending dengan kenaikan anggaran periode berikutnya, yang berarti adanya bias dalam penentuan target anggaran pemerintah daerah.

\section{KESIMPULAN DAN IMPLIKASI}

Penelitian ini menunjukkan hasil bahwa nilai $\mathrm{t}$ hitung $>\mathrm{t}$ tabel, sehingga dapat ditarik kesimpulan bahwa pendapatan asli daerah berpengaruh terhadap belanja daerah dan hal ini menandakan bahwa hipotesis pertama diterima. Hal ini juga memberikan hubungan yang positif sehingga apabila pendapatan asli daerah terjadi kenaikan maka belanja daerah akan terjadi juga kenaikan.

Efek Ratcheting adalah variabel moderasi yang berfungsi untuk memperkuat antara hubungan pendapatan asli daerah dengan belanja daerah. Hasil uji tentang efek Ratcheting mengalami penurunan pada Adjusted R Square. Maka dari itu, dapat disimpulkan bahwa efek 
ratcheting mempelemah antara hubungan pendapatan asli daerah dengan belanja daerah. Saran untuk penelitian selanjutnya adalah agar Menambah atau memperluas sampel penelitian dengan cakupan yang lebih luas. Menambah data penelitian dengan jangka waktu atau periode anggaran yang lebih panjang. Membuat variabel Efek Ratcheting sebagai variabel terikat, yang mungkin akan memberikan hasil analisis yang berbeda.

\section{DAFTAR PUSTAKA}

Abdullah, S., \& Afrah, J. (2016). "Bukti Empiris Pengaruh Budget Ratcheting terhadap Hubungan antara Pendapatan Sendiri dan Belanja Daerah pada Kabupaten/Kota di Aceh”. Modus 28(2), 185-201.

Abdullah, S., \& Nazry, R. (2015). "Analisis Varian Anggaran Pemerintah Daerah Penjelasan Empiris dari Perspektif Keagenan”. Jurnal Samudra Ekonomi dan Bisnis 6(2), 272-283.

Akbar, R., Pilcher, R., \& Perrin, B. (2012). 'Performance measurement In Indonesia: The case of local government'. Pacific Accounting Review 12(3), 262-291.

Al-Khawarizmi, D. A. (2011). Negara Hukum. Retrieved from www.negarahukum.com: https://www.negarahukum.com/hukum/pendapatan-asli-daerah.html.

Aranda, C., \& Arellsno, J. (2010). "Ratcheting Effect and The Role of Relative Target Setting". Working Papers. Spain: University of Navarra.

Bastian, I. (2001). Akuntansi Sektor Publik di Indonesia. Yogyakarta: BFE-Yogyakarta.

Bastian, I. (2006). Akuntansi Sektor Publik: Suatu Pengantar. Jakarta: Erlangga.

Bawono, I. R., Halim, A., \& Lord, B. (2012). "Public Sector Performance Measurement and Budget Allocation: an Indonesian Experiment". artikel dipresentasikan di the 6th NZ Management Accounting Conference, New Zealand.

Fisher, J. G., Frederickson, J. R., \& Peffer, S. A. (2006). "Budget Negotiations In Multi-Period Settings". Accounting, Organizations and Society 31(6), 511-528.

Fisher, J. G., Frederickson, J. R., \& Preffer, S. A. (2002). "The Effect of Information Asymmetry on Negotiated Budgets: An Empirical Investigation". Accounting, Organizations and Society 27(1), 27-43.

Gischa, S. (2020). Kompas.com. Retrieved from www.kompas.com: https://www.kompas.com/skola/read/2020/01/18/180000269/apbd--pengertian-unsurjenis-fungsi-dan-tujuannya.

Halim, A., \& Abdullah, S. (2010). "Hubungan dan Masalah Keagenan di Pemerintah Daerah". Jurnal Akuntansi Pemerintah 2(1), 53-64.

Kementrian Keuangan (DIREKTORAT JENDERAL PERIMBANGAN KEUANGAN). (n.d.). Retrieved from http://www.djpk.kemenkeu.go.id: http://www.djpk.kemenkeu.go.id/?ufaq=apa-yang-dimaksud-dengan-belanja-daerah.

Lee, T. M., \& Plummer, E. (2007). "Budget Adjustments In Response to Spending Variances: Evidence of Ratcheting of Local Government Expenditures". Journal of Management Accounting Research 19(1), 137-167.

Leone, A. J., \& Rock, S. (2002). "Empirical Tests of Budget Ratcheting and Its Effect On Managers' Discretionary Accrual Choices". Journal of Accounting and Economics 33(1), 43-67.

Mardiasmo. (2009). Serial otonomi daerah: Otonomi dan manajemen keuangan daerah. Yogyakarta: Andi Publisher. 
Marlina, L. (2019). "Efek Ratcheting dalam Anggaran Belanja Daerah pada Pemerintah Kabupaten/Kota di Provinsi Aceh". Jurnal Akbis, 3(1).

Marlowe, J. (2009). "Budget Variance, Slack Resources, and Municipal Expenditures". SSRN Library.

Ndadari, L. W., \& Adi, P. H. (2008). "Perilaku Asimetris Pemerintah Daerah terhadap Transfer Pemerintah Pusat"'. Artikel dipresentasikan di The 2nd National Conference UKWMS. Surabaya.

Nordiawan, D., \& Hertianti, A. (2010). Akuntansi Sektor Publik. Jakarta: Salemba Empat.

Ritonga, I. T., Clark, C., \& Wickremasinghe, G. (2012). “Assessing Financial Condition of Local Government in Indonesia: An Exploration". Public and Municipal Finance 1(2), 37-50.

Sari, V. N., Suhairi, \& Syofriyeni, N. (2020). 'Efek Ratchet terhadap Anggaran Pemerintah Daerah: Studi pada Pemerintah Kota se-Sumatera'. Jurnal Ilmiah Universitas Batang Hari Jambi, 20(1), 183-186.

Susanto, A. A., \& Halim, A. (2018). "Efek Ratchet pada Anggaran Pemerintah Daerah: Studi pada Satuan Kerja Perangkat Daerah Pemerintah Provinsi Daerah Istimewa Yogykarta". Jurnal Akuntansi dan Akuntabilitas Publik, 88-96.

Voorhees, W. (2006). "Consistent Underesti-Mation Bias, The Asymmetrical Loss Function, and Homogenous Sources of Bias In State Revenue Forecast”. Journal of Public Budgeting Accounting \& Financial Management 18(1), 61-76. 